\title{
Association of Paraoxonase-1(Q192R and L55M) Gene Polymorphisms and Activity with Colorectal Cancer and Effect of Surgical Intervention
}

\author{
Nagwa S Ahmed ${ }^{1 *}$, Noha M Shafik², Omar Abd Elraheem³ , Saad-Eldin A Abou- \\ Elnoeman ${ }^{2}$
}

\begin{abstract}
Background: Colorectal cancer (CRC) is a leading cause of cancer-related death. Oxidative DNA damage may contribute to cancer risk and the antioxidant paraoxonase is one endogenous free radical scavenger in the human body which could therefore exert an influeence. Purpose: Aim of this study was to determine the role of serum arylesterase (ARE) and paraoxonase 1(PON1) activities in CRC patients and to find any association between (PON1) Q192R and L55M gene polymorphisms in CRC patients. Also the serum ARE and PON1 activities in CRC patients will be investigated before and after surgery Materials and Methods: This study involved a total of 50 patients with newly diagnosed $C R C$ and 80 healthy controls. PON1 and ARE activities were determined using an enzymatic spectrophotometric method. PON1 Q192R and L55M gene polymorphisms were determined using polymerase chain reaction-restriction fragment length polymorphism (PCR-RFLP) based restriction fragment analysis. The restriction enzyme AlwI was used to examine the Q192R polymorphism and Hsp92II for the L55M polymorphism. Results: Significant differences in the PON1 Q192R polymorphism were found between patients and controls. The $Q$ allele was more frequent in the patient group than in controls, while the $R$ allele was more frequent in the controls. Significant differences were found in the L55M polymorphism. Additionally, there were significant differences in $L$ and $M$ allele frequencies $(p=0.001)$. The serum activities of PON1 and ARE were low in QQ and MM genotype. Conclusions: serum PON1 and ARE activities were significantly lower in CRC patients compared to healthy subjects. The $R$ allele may protect against colorectal cancer.
\end{abstract}

Keywords: Colorectal cancer - paraoxonase-1 - Q192R and L55M gene polymorphisms

Asian Pac J Cancer Prev, 16 (2), 803-809

\section{Introduction}

Colorectal cancer (CRC) is the term for colon or rectum malignant epithelial tumor. $\mathrm{CRC}$ is an important global health problem. CRC is the third most common type worldwide, making it the fourth most common cause of cancer-related death (Aiello et al., 2011). The etiology of CRC remains elusive. It is estimated that up to $10 \%$ of CRC cases may be due to hereditary factors (Lichtenstein et al., 2000; Aaltonen et al., 2007), while the other of $90 \%$ of CRC cases (sporadic cases) may be attributable to various environmental and lifestyle factors, such as dietary habits, obesity and physical inactivity. Genetic predisposition to CRC may involve polymorphic variations in genes encoding for antioxidant enzymes (Loft et al., 2008). Genetic variations in antioxidant enzymes may affect the pattern of colonic expression and modulate the ability of gut epithelial cells to cope with damaging metabolic challenges and possibly altering the risk for CRC. In addition it has been suggested that there an association between oxidative stress and CRC. Moreover it was found that the human colorectal carcinomas have increased levels of different markers of oxidative stress, such as increased levels of reactive oxygen species (ROS) may also play a role in developing CRC (Mena et al., 2009; Vermorken et al., 2014).

Human serum paraoxonase (PON) and arylesterase (ARE) are antioxidant enzymes (Ellidag et al., 2014) synthesized in the liver. PON genes are located in the q21.3 region of the long arm of chromosome 7 (Connolly et al., 2003). The human paraoxonase -1 (PON1) enzyme is a polymorphic, found in plasma together with high density lipoprotein cholesterol (HDL-C high density and it plays important role in preventing the oxidation of plasma lipoproteins (Mackness et al., 1991; It is an esterase enzyme metabolizes many different substrates including organophosphurus (OPs) compounds and drugs (Davies et al., 1996; Li et al., 2003) . There are two polymorphisms in the PON1 coding region at positions Gln192 $\rightarrow$ Arg (Q192R) and Leu55 $\rightarrow$ Met (L55M).

${ }^{1}$ Department of Medical Biochemistry, Faculty of Medicine, Tanta University, Tanta,${ }^{2}$ Department of Medical Biochemistry, ${ }^{3}$ General Surgery, Faculty of Medicine, Sohag University, Sohag, Egypt*For correspondence:dr_nagwa69@yahoo.com 
Q192R have been more widely studied, because the two alloenzymes have different affinities and catalytic activities towards a number of substrates. Studies showed that polymorphisms of PON1 gene may change PON1 activity. In a study by Eckerson et al. (1983) the PON1 activity of PON1 192 Q allele carriers was reported to be lower than that of the R carriers. Reduced PON1 activities have been reported in some malignancy such as gastric and pancreatic carcinoma. Although the association of PON1 polymorphisms and its serum activity were elucidated in several types of malignant tumors such as cancer ovary lung and liver (Aksoy-Sagirli et al., 2011; Lurie et al., 2008), the relationship between PON1and ARE activity and CRC was not fully investigated and there is only few published papers so far studied the association between PON1 Q192R and L55M and CRC (Van der Logt et al ., 2006, Ellidag et al., 2014 ). We assume that PON1, which has anti-inflammatory and antioxidant effects, may have role in CRC caused by inflammation and oxidative stress. Therefore the aim of the present work was to investigate the role of serum PON1 activities and genotypes in CRC patients and controls. Moreover this study will be extended to determine the serum PON1 and ARE activities before and after surgical interferences .

\section{Materials and Methods}

\section{Patients}

Fifty newly diagnosed CRC patients (14 females, 36 males; mean age $58.44 \pm 3.74$ years) admitted to the Outpatient Clinic of Surgery Sohag University Hospital, were included in the present study. The diagnosis of patient was done clinically and confirmed by the microscopic evaluation of colonoscopic biopsy samples, followed by total excision of tumors. The following pathologic findings were assessed: according to modified Dukes classification (stage $A=6$ cases, stage $B=24$ cases, stage, $\mathrm{C}=14$ cases and stage $\mathrm{D}=6$ cases). Eighty healthy control subjects of corresponding gender and age (24 females and 56 males; mean age: $44.45 \pm 2.88$ years) were also enrolled for comparison. Any patient under treatment with antioxidant drugs was excluded. Written informed consent was obtained from every patients and control to be enrolled in the study after explanation of study details. The study was approved by the Ethical Committee Faculty of Medicine Sohag University.

\section{Methods}

$10 \mathrm{~mL}$ of venous blood was collected from all subjects preoperative after 12 hours of fasting Each sample was divided into two halves, one half for serum preparation. Serum samples were separated by centrifugation and stored at $-20^{\circ} \mathrm{C}$ until assayed. The other half was put into tubes containing EDTA for DNA extraction. The postoperative blood samples were collected from 44patients one month postoperative (there were 6 cases who missed to follow up) and were stored at $-20^{\circ} \mathrm{C}$ until assay.

\footnotetext{
1-Determination of Plasma Lipids and tumor markers

Total cholesterol and high density lipoprotein cholesterol (HDL-C) were determined as routine
}

parameters by using commercially available assay kits by Human Company (Germany) (Richmond, 1973; Grove, 1979) respectively. Triglycerides were determined by using colorimetric method using commercial kit supplied by Spinreact Company (Spain) (Fossati and Prencipe, 1982). Low density lipoprotein cholesterol (LDL-C) was estimated using Friedewald's formula (Friedewald et al., 1972): LDL-C=total cholesterol-(HDL cholesterol + triglycerides/5) $\mathrm{mg} / \mathrm{dl}$. The levels of serum alpha fetoprotein (AFP) and carcinoembryonic antigen (CEA) were measured before and after one month from the operation by ELISA commercial kits supplied by CloudClone Corp (Hu et al., 2013).

\section{2-Determination of PON1 activity}

PON1 activity was measured by adding $20 \mu \mathrm{l}$ of serum to Tris buffer (100 mmol/l, $\mathrm{pH} \mathrm{8.0)} \mathrm{containing} 2$ $\mathrm{mmol} / \mathrm{l} \mathrm{CaCl}$ and $1 \mathrm{mmol} / \mathrm{l}$ paraoxon $(\mathrm{O}$, O-diethyl-Onitrophenylphosphate (Sigma) The rate of generation of P-nitrophenol was determined at $405 \mathrm{~nm}, 37^{\circ} \mathrm{C}$ over 50 second after 1 minute lag time with the use of continuously recording spectrophotometer as described previously by Eckerson et al. (1983) and Mackness et al. (1991).

\section{3-Determination of ARE Activity}

ARE activity was measured using phenylacetate as a substrate as previously described by Kilic et al (2005) The reaction mixture contained $750 \mu \mathrm{l}$ of $0.1 \mathrm{~mol} / 1$ Tris$\mathrm{HCl}(\mathrm{pH} 8.5), 1 \mathrm{mmol} / \mathrm{C} \mathrm{CaCl}_{2}, 125 \mu \mathrm{l}$ of $12 \mathrm{mmol} / \mathrm{l}$ phenylacetate and $125 \mu \mathrm{l}$ of diluted serum (1:10 diluted with water). Initial rates of hydrolysis were determined by following the increase of phenol concentration at $270 \mathrm{~nm}$ at $37^{\circ} \mathrm{C}$. Enzyme activities were expressed in international units per 1 liter of serum (U/l). An international unit is the amount of hydrolyzed substrate in $\mathrm{mmol} /$ minute.

\section{4- Polymorphism analysis}

Genomic DNA was extracted from EDTA -blood samples using extracting kit (CinnaPure DNA Cat No. PR881612. Tehran) as described in the user manual. The quality of genomic DNA was tested using agarose gel electrophoresis. As previously described by Adkins et al (1993), PCR-RFLP method was used to determine the PON1 192 and PON1 55 gene polymorphisms. PCR was used to amplify the gene with 5'-TAT TGT TGC TGT GGG ACC TGA G-3' and 5'-CAC GCT AAA CCC AAA TAC ATC TC-3' primers for determination of the PON1 192 gene polymorphism and 5'-GAA GAG TGA TGT ATA GCC CCA G-3' and 5'-TTT AAT CCA GAG CTA ATG AAA GCC-3' for the PON1 55 polymorphism. The PCR mixture (total, $25 \mu \mathrm{l}$ ) containing $100 \mathrm{ng}$ DNA, $1 \mu \mathrm{l}$ of each primer, $5 \mu \mathrm{ldNTP}, 1.5 \mu \mathrm{l}$ of $\mathrm{MgCl}_{2}$ and $0.3 \mu \mathrm{l}$ Taq polymerase. For the PON1 192 gene polymorphism, the mixture was incubated at $95^{\circ} \mathrm{C}$ for 2 minutes, then 35 cycles of $94^{\circ} \mathrm{C}$ for 1 minute to denature, $61^{\circ} \mathrm{C}$ for 1 minute to anneal the primers and $72^{\circ} \mathrm{C}$ for 1 minute to elongate the strand PCR ,amplification kit was obtained from (CinnaGen Co.Cat No. PR8252C, Tehran). After PCR process, the Alw1 (BspI) (Biolabs Cat. No. R0513SEngland) restriction enzyme was used and $2 \%$ agarose gel electrophoresis was performed to identify the possible 
polymorphism. Alw1 (BspI) digestion generated the following fragments: PON1 $192 \mathrm{R}$ allele, fragments of $66 \mathrm{bp}$ and 33 bp; PON1 192 Q allele, a single fragment of $99 \mathrm{bp}$. For the determination of the PON1 55 locus polymorphism, the PCR reactions started with incubation at $95^{\circ} \mathrm{C}$ for 5 minutes and 30 cycles of denaturation for 1 minute at $92^{\circ} \mathrm{C}$, followed by annealing for 45 seconds at $52^{\circ} \mathrm{C}$ and elongation for 45 seconds at $72^{\circ} \mathrm{C}$. The restriction enzyme was N1a111 (Hsp92II) (Biolabs Cat. No. R0125S- England) was used for determination of the PON1 55. N1a111 (Hsp92II) digestion generated the following fragments: for PON1 $55 \mathrm{M}$ allele, fragments of $126 \mathrm{bp}$ and $44 \mathrm{bp}$; for PON1 $55 \mathrm{~L}$ allele, a single fragment of $170 \mathrm{bp}$. The digested PCR products of the two PON1 polymorphisms were separated on 3\% agarose and visualized using ethidium bromide.

\section{5-Statistical analyses}

The data were statistically analyzed Using SPSS software version 16, 0 (SPSS Inc, Chicago, IL, USA). In normally distributed groups the results were presented as mean and SD. The significance of the differences between groups was determined by Student's unpaired t-test and by the Mann-Whitney U-test in abnormal distribution. The association between PON-1 192, 55 genotypes between CRC patient and control was examined by Chi-square , Odds ratios (OR) and 95\% confidence intervals (95\%CI) were calculated to risk factor for CRC The distributions of genotypes were tested by Hardy-Weinberg equilibrium (HWE) (with $\mathrm{df}=\mathrm{N}-2$ ). $\mathrm{p}$ value of 0.05 was considered statistically significant. The Pearson's correlation analysis was used to assess the relationship between different parameter

\section{Results}

\section{Demographic and biochemical characteres}

Comparing the lipid profile in CRC patients and control, The serum total cholesterol (TC), triglycerides (TG), LDL-C levels in patients with CRC were significantly higher compared to control $(\mathrm{p}<0.001)$ (Table 1). Serum HDL cholesterol was significantly lower $(\mathrm{p}<0.001)$ in the cancer patients as compared with controls. The serum activity of PON1 and ARE were lower in CRC patients compared to controls which was statistically significant (272.6 \pm 118.82 and197.3 \pm 72.15 activity (U/L) respectively versus394.1 \pm 83.44 and $228.4 \pm 83.43$ activity (U/L) respectively in control. There was significant correlation between PON1 and ARE activities in patient group. The PON1 activity was standardized with HDL concentrations (PON1/HDL ratio). It was found that PON1 /HDL is low in CRC patients (7.469 \pm 1.8 versus $8.42 \pm 2.6$ $\mathrm{P}$ value 0.025).It is obvious that the PON1/ARE ratio was low in patients as compared with control (1.229 \pm 0.3 and $1.725 \pm 0.4$ respectively) Furthermore serum levels of AFP and CEA were statistically significant higher in the CRC patient compared with control $(33.41 \pm 4.65$ and $17.96 \pm 2.3(\mathrm{ng} / \mathrm{ml})$ versus $1.65 \pm 0.19$ and $1.5 \pm 0.11(\mathrm{ng} / \mathrm{ml})$ $\mathrm{p}$ value $<0.001)$. activities of (PON1,ARE) and tumor markers (AFP,CEA)

It is clear from Table 2 that surgery has an effect on the antioxidants enzymes activity and tumor markers levels. Mean serum activity of PON1 and ARE were increased significantly after one month from surgery and the activity of these enzymes almost reached normal levels $(272.60 \pm 118.82$ and $197.3 \pm 72.15$ versus $374.09 \pm 81.84$ and $218.40 \pm 13.17$ respectively). Also serum levels of AFP and CEA decreased significantly after one month from surgery (33.41 \pm 4.65 and $17.96 \pm 2.3$ versus $5.74 \pm 0.89$ and $3.32 \pm 1.8$ respectively).

\section{Distribution of PON1 gene polymorphisms}

Table 3 showed the distribution of PON1 L55M and PON1 Q192R genotypes was consistent with HardyWeinberg equilibrium in cases and control. For the PON1 gene L55M polymorphism, the LL genotype was the most common genotype and it was found in $38(76 \%)$ patients, whereas the LM genotype was found in 10 (20\%) patients and the MM genotype was present in $2(4 \%)$ patients. In the control group, LL, LM and MM genotypes were found in $40(50 \%), 24(30 \%)$, and $16(20 \%)$ subjects, respectively. As regard the risk of development of $\mathrm{CRC}$, our data indicated that LL homozygous is more $(\mathrm{OR}=3.167,95 \% \mathrm{CI}=1.447-6.93 . \mathrm{p} \leq 0.003)$ but the MM homozygous is less (OR, $0.166795 \% \mathrm{CI}=0.036-0.760$, $\mathrm{p} \leq 0.010)$. No significant association was observed between (LM) genotype and CRC risk $(\mathrm{OR}=0.58,95 \%$ $\mathrm{CI}=0.251-1.354, \mathrm{p}=0.207)$. The frequency of $\mathrm{L}$ showed increased risk for CRC. Frequency of $\mathrm{L}$ and $\mathrm{M}$ in patients versus control 86(86\%), 104(65\%), 14(14\%), 56(35\%) respectively. Analysis the data for $\mathrm{L}$ and $\mathrm{M}$ alleles revealed

Table 1. Demographic and Biochemical Characters of CRC Patients and Controls

\begin{tabular}{lccr}
\hline & $\begin{array}{c}\text { Patients } \\
(\mathrm{n}=50)\end{array}$ & $\begin{array}{c}\text { Control } \\
(\mathrm{n}=80)\end{array}$ & p value \\
\hline Age (years) & $58.44 \pm 3.74$ & $44.45 \pm 2.88$ & $<0.001^{*}$ \\
Gender Female & $17(28 \%)$ & $24(30 \%)$ & NS \\
\multicolumn{1}{c}{ Male } & $36(72 \%)$ & $56(70 \%)$ & \\
TC(mg/dl) & $175.7 \pm 19.08$ & $164.9 \pm 2.92$ & $<0.001^{*}$ \\
HDL-C(mg/dl) & $32.5 \pm 10.75$ & $46.8 \pm 12.08$ & $<0.001^{*}$ \\
LDL-C(mg/dl) & $152.3 \pm 22.85$ & $90.41 \pm 20.8$ & $<0.001^{*}$ \\
TG(mg/dl) & $159.8 \pm 23.83$ & $144.2 \pm 32.8$ & $0.004^{*}$ \\
PON-1 activity(U/L) & $272.6 \pm 118.82$ & $394.1 \pm 83.44$ & $<0.001^{*}$ \\
ARE activity (U/L) & $197.3 \pm 72.15$ & $228.4 \pm 83.43$ & $0.031^{*}$ \\
PON-1/ ARE ratio & $1.229 \pm 0.3$ & $1.725 \pm 0.4$ & $<0.001^{*}$ \\
PON-1/ HDL ratio & $7.469 \pm 1.8$ & $8.42 \pm 2.6$ & $0.025^{*}$ \\
AFP(ng/ml) & $33.41 \pm 4.65$ & $1.65 \pm 0.19$ & $<0.001^{*}$ \\
CEA(ng/ml) & $17.96 \pm 2.3$ & $1.5 \pm 0.11$ & $<0.001^{*}$ \\
\hline
\end{tabular}

Data are expressd as mean $\pm \mathrm{SD}$; $\mathrm{t}$ : Student $\mathrm{t}$-test; *Statistically significant at $\mathrm{p} \leq 0.05$; NS: Not statistically significant

Table 2. Comparison between preoperative and postoperative (after one month) activities of (PON1, ARE) and tumor markers (AFP, CEA)

\begin{tabular}{lccc}
\hline & $\begin{array}{c}\text { preoperative } \\
(\mathrm{n}=50)\end{array}$ & $\begin{array}{c}\text { postoperative } \\
(\mathrm{n}=44)\end{array}$ & $\mathrm{p}$ value \\
\hline PON-1 activity(U/L) & $272.60 \pm 118.82$ & $374.09 \pm 81.84$ & 0.0001 \\
$\mathrm{ARE}$ activity(U/L) & $197.3 \pm 72.15$ & $218.40 \pm 13.17$ & 0.0001 \\
$\mathrm{AFP}(\mathrm{ng} / \mathrm{ml})$ & $33.41 \pm 4.65$ & $5.74 \pm 0.89$ & 0.0001 \\
$\mathrm{CEA}(\mathrm{ng} / \mathrm{ml})$ & $17.96 \pm 2.3$ & $3.32 \pm 1.80$ & 0.0001 \\
\hline Data are expressed as mean \pm standard deviation & &
\end{tabular}


Table 3. Distribution of PON1 (Q192R and L55M) genotype frequency and alleles frequency in the CRC patients and controls

\begin{tabular}{rlrcccc}
\hline & Genotype & CRC patients $(\mathrm{n}=50)$ & Control $(\mathrm{n}=80)$ & Odds ratio & 95\%CI & $\mathrm{p}$ value \\
\hline PON-1 55 & LL & $38(76 \%)$ & $40(50 \%)$ & 3.167 & $1.447-6.930$ & $0.003^{*}$ \\
& LM & $10(20 \%)$ & $24(30 \%)$ & 0.583 & $0.251-1.354$ & 0.207 \\
& MM & $2(4 \%)$ & $16(20 \%)$ & 0.1667 & $0.0366-0.760$ & $0.010^{*}$ \\
& L Allele & $86(86 \%)$ & $104(65 \%)$ & 3.308 & $1.724-6.346$ & $<0.001^{*}$ \\
& M Allele & $14(14 \%)$ & $56(35 \%)$ & 0.302 & $0.158-0.580$ & $<0.001^{*}$ \\
PON-1 192 & QQ & $30(60 \%)$ & $20(25 \%)$ & 4.500 & $2.106-9.613$ & $<0.001^{*}$ \\
& QR & $16(32 \%)$ & $36(45 \%)$ & 0.575 & $0.275-1.205$ & 0.141 \\
& RR & $4(8 \%)$ & $24(30 \%)$ & 0.203 & $0.066-0.627$ & $0.003 *$ \\
& Q Allele & $76(76 \%)$ & $76(47.5 \%)$ & 3.500 & $2.011-6.091$ & $<0.001^{*}$ \\
& R Allele & $24(24 \%)$ & $84(52.5 \%)$ & 0.286 & $0.164-0.497$ & $<0.001^{*}$ \\
\hline
\end{tabular}

Table 4. PON1 and ARE activity in the control and CRC patients according to PON1 192 and 55 genotypes

\begin{tabular}{lccccc}
\hline & & \multicolumn{2}{c}{ PON1 (U/L) } & \multicolumn{2}{c}{ ARE (U/L) } \\
& & Patients & Control & Patients & Control \\
\hline PON192 & QQ & $159.9^{\mathrm{a}} \pm 30.65$ & $319.1^{\mathrm{a}} \pm 87.48$ & $193.1^{\mathrm{a}} \pm 97.34$ & $228.4^{\mathrm{a}} \pm 63.43$ \\
& QR & $129.7^{\mathrm{a}} \pm 29.76$ & $395.1^{\mathrm{b}} \pm 111.44$ & $195.5^{\mathrm{a}} \pm 87.23$ & $215.4^{\mathrm{a}} \pm 77.87$ \\
& RR & $95.6^{\mathrm{a}} \pm 20.43$ & $485.1^{\mathrm{c}} \pm 83.44$ & $197.5^{\mathrm{a}} \pm 89.45$ & $258.4^{\mathrm{a}} \pm 86.43$ \\
& F & 2.153 & $15.854^{*}$ & 0.006 & 2.248 \\
& p & 0.127 & $<0.001^{*}$ & 0.994 & 0.112 \\
PON-1 55 & LL & $234.4^{\mathrm{a}} \pm 85.99$ & $397.6^{\mathrm{a}} \pm 101.55$ & $198.2^{\mathrm{a}} \pm 95.22$ & $298.4^{\mathrm{a}} \pm 101.43$ \\
& LM & $201.2^{\mathrm{a}} \pm 97.35$ & $329.1^{\mathrm{b}} \pm 98.46$ & $197.8^{\mathrm{a}} \pm 87.66$ & $249.4^{\mathrm{ab}} \pm 93.78$ \\
& MM & $194.6^{\mathrm{a}} \pm 103.67$ & $284.1^{\mathrm{a}} \pm 93.55$ & $195.3^{\mathrm{a}} \pm 97.37$ & $236.4^{\mathrm{b}} \pm 63.53$ \\
& F & 0.154 & $8.606^{*}$ & 0.001 & $3.500^{*}$ \\
& p & 0.858 & $<0.001^{*}$ & 0.999 & $0.035^{*}$ \\
\hline
\end{tabular}

Different superscripts are significant; Data are expressed as mean \pm standard deviation; F: F test (ANOVA); *Statistically significant at $\mathrm{p} \leq 0.05$

$(\mathrm{OR}=3.3,95 \% \mathrm{CI}=1.72-6.346 \mathrm{p}=0.001$ and $\mathrm{OR}=0.302$, $95 \% \mathrm{CI}=1.58-0.580, \mathrm{p}=0.001$ ) respectively.

The genotype frequency of PON1 Q192R showed that the homozygous (QQ) was the most common genotype followed by heterozygous (QR), and homozygous mutated gene (RR) and their frequencies were $30(60 \%), 16$ ( $32 \%)$ and $4(8 \%)$ in CRC patients, respectively; and 20 (25\%), $36(45 \%)$ and $24(30 \%)$ in controls, respectively. The Q allele frequency was found in $76(76 \%)$ in CRC patients and $76(47.5 \%)$ in controls, while mutated $\mathrm{R}$ allele frequency in CRC patients and controls was 24 (24\%) and $84(52.5 \%)$ respectively. The analysis of our data showed that there was an association between QQ genotypes and risk of CRC. $(\mathrm{OR}=4.500,95 \% \mathrm{CI} 2.106-9.613, \mathrm{p}<0.001)$ but less in $\mathrm{RR}$ and $\mathrm{QR}(\mathrm{OR}=0.203,95 \% \mathrm{CI}=0.066$ $0.6270, \mathrm{p}<003, \mathrm{OR}=0.575,95 \% \mathrm{CI}=0.275-1.205, \mathrm{p}=0.141$ ) respectively. However there was no an association found between QR heterozygous genotype and developing risk for CRC. The frequency of $\mathrm{Q}$ allele showed increased risk for CRC frequency of $\mathrm{Q}$ in patients versus control is 76 (76\%) , $76(47.5 \%)$ but less in $\mathrm{R}$ allele in patients versus control is $24(24 \%)$ and $84(52.5 \%)$ respectively.

Serum PON1 and ARE activities in different genotypes of PON 1192 and PON1 55.

Table 4 showed that, serum PON1 activities were statistically significantly lower in PON1 Q192R and PON1 L55M genotypes carrier in CRC patient compared to the control group. As regard ARE enzyme activity in PON1 192/55 genotypes no significantly difference was observed between patients and control. PON1 activity was significantly higher in PON1 RR and PON1 55 LL genotype carriers in controls compared to that of the other genotypes (QQ, QR and MM, LM, respectively) $(p<0.001)$. Although there was difference in enzyme activities of PON1 and ARE among different genotypes and alleles of PON1 192/55, in patients group, this difference did not reached significant levels.

Correlation between tumor markers and antioxidant enzymes in CRC patients

By using Pearson coefficient, there is a significant positive correlation between PON1 enzyme activity and HDL-C $\left(r=0.868^{*}\right.$ and $\left.\mathrm{p}<0.001\right)$. However, there is a negative correlation between ARE enzyme activity and HDL-C ( $r=-0.090$ and $p=0.534)$. Also there was a positive significant correlation between PON1 enzyme activity and ARE enzyme activity in $\mathrm{CRC}$ patients $(\mathrm{r}=0.152, \mathrm{p}=0.045)$ mean while there was a negative correlation between serum level of AFP, CEA and PON1 and ARE enzyme activities $(\mathrm{r}=-0.082, \mathrm{p}=0.433$ and $\mathrm{r}=-0.056, \mathrm{p}=0.594)$ for AFP respectively and for CEA $(r=-0.016, p=0.880$, $r=-$ $0.255, \mathrm{p}=0.13$ ) respectively.

\section{Discussion}

It has been indicated that PON1 deficiency induced an increase in oxidative stress and there is an inverse relationship between serum PON1 and ARE activities and oxidative stress (Kumon et al., 2003). In our study, the serum PON1 and ARE activities and PON1/ARE ratio were found to be significantly lower in patients with CRC compared to controls. Several studies have indicated decreased PON1 and/or ARE activities in different types 
of cancer (Kilic et al., 2005; Vecka et al., 2012; Bulbuller et al., 2013). Furthermore, the serum lipid profile of CRC patients was statistically higher than controls. To test whether the decrease in the serum activity of PON1 was caused by reduction in HDL-C level or in enzyme activity, we calculated the PON1/ HDL ratio and we found that ratio was low in patients compared to controls. Positive correlation was found between serum PON1 activity and serum levels of HDL-C. These results revealed that serum PON1 activity reduction did not dependent on HDL-C concentration in patients group. Our results were supported and confirmed by the results of two recent reports done by Balci et al. (2012) and Bulbuller et al. (2013) who demonstrated Low plasma paraoxonase/arylesterase activities in CRC Turkish patients. The mechanism of the reduction of serum PON1 and ARE activities in CRC patients is not clearly understood. This reduction could be related to increased lipid peroxidation, since oxidized lipids are reported to inhibit PON1 and ARE activities (Jayakumari and Thejaseebai, 2009). Furthermore the decrease in the activity of PON1 and ARE in CRC patients may be due to inhibition of PON1 and ARE by generated carcinogenic lipids in cancer patients. Lower levels of PON1 may increase the CRC vulnerability to genomic damage by reducing the ability to detoxify inflammatory oxidants as well as dietary carcinogens. In addition, the activity of PON1 has been reported to be significantly reduced in some conditions accompanied the oxidative stress such as malignant tumors. Similarly PON1 activity in patients with CRC may be a result of elevated activity of ROS in CRC (Mena et al., 2009; Vermorken et al., 2014). PON1 is highly localized in colon and associated with the development of CRC is consistent with the antiinflammatory role of this enzyme. PON1 activity is also reduced among patients with chronic colitis and possibly CRC cancer (Balci et al., 2012; Unal et al., 2012; Alkhouri et al., 2014).

In our study we get step further by determination PON1 and ARE enzyme activity one month after removal of tumor by surgery. Our results indicated that the activities of these enzymes and serum levels of CEA and AFP returned almost to normal levels. Our result may be explained by the removal of the tumor leading to decrease generation of free radicals and carcinogenic product of oxidative stress (Hristozov et al., 2001). The change occurred in serum PON1 and is activity before and after surgery is similar to changed in serum level of CEA and AFP. Therefore serum PON1 and AER may be used as markers for evaluation of tumor diagnosis and prognosis .This observation was not recorded before and required further investigation in different kinds of cancers.

Several studies have shown that there is an association between PON1 (Q192R and L55M) gene polymorphisms and different types of cancer including cancer breast, bladder, prostate, ovarian cancer, pancreatic cancer and gastrointestinal tumor (Lincz et al., 2004; Antognelli et al., 2005; Stevens et al., 2006; Lurie et al., 2008). However data are conflicting and other studies failed to find any association with cancer and PON1 (Q192R and L55M) gene polymorphisms (Gold et al., 2009; Akkız et al., 2013). To the best of our knowledge, we presented here the first study that investigated the association of PON1 gene polymorphisms and activities of PON1 and ARE in CRC patients.

As regards PON1 L55M polymorphism, our results revealed that the frequencies LL genotypes and $\mathrm{L}$ allele were significantly higher in the CRC patients than in controls; moreover, in patients having LL genotype, the risk of CRC is increased up to 3.167 fold. Investigators of PON 1 L55 in relation to cancer ovary reported higher risk associated with the genotype, which is consistent with our results (Arpaci et al., 2009). The results of this study are inconsistent with the previous study of Van der Logt et al. (2006) who did not find any differences between distributions of genotype and allele frequencies between patients and controls. The discrepancy in results may be due to selection of cases and different ethnic group. Our results can be explained by that PON1 55 LL genotype may alter the activity of enzyme by certain mechanism that leads to developing CRC due to reduction in antioxidant and anti-inflammatory activities. Our study indicated that there was an association and reduced risk of CRC in patients carried PON1-55M genotype. The PON1-55M variant is associated with a high enzyme activity which could mean that the conversion rate of carcinogenic compounds is increased and that these compounds may accumulate in the colonic lumens which make the epithelial of colon more vulnerable for production of colorectal carcinoma.

Several studies indicated that there is an association between PON1 192 QQ genotype and an increased risk of lung, breast and prostate cancer and osteosarcoma (Antognelli et al., 2005; Gallicchio et al., 2007; AksoySagirli et al., 2011; Ergen et al., 2011). Other studies showed that the $\mathrm{R}$ allele is associated with an increased risk of ovarian cancer, non-Hodgkin's lymphoma, bladder cancer and multiple myeloma (Lincz et al., 2004; De Roos et al., 2006; Lurie et al., 2008; Ozturk et al., 2009). Our results showed that PON1 192 QQ genotype and Q allele are significant risk factors for $\mathrm{CRC}$ in which, the risk of CRC were increased up to 4.5 fold. Also, there was a marked reduction in the frequency of PON1 $192 \mathrm{R}$ allele in patients which mean that $\mathrm{R}$ allel was associated with decreased risk of CRC. Our results do not agree with results of Vander Logt et al. (2006). Similar results were reported by Antognelli et al. (2005) who found that PON192/QQ was associated with a significant increased risk of prostate cancer. Also, Gallicchio et al. (2007) showed that $\mathrm{R}$ allele was associated with decreased risk of bladder cancer. They explained their results by that the $\mathrm{Q}$ to $\mathrm{R}$ substitution leads to the production of an enzyme with a higher detoxification activity against potentially carcinogenic products of oxidative stress and lipid peroxidation. In another study by Lee et al. (2005), have shown that carriers of the PON1 192 QQ genotype have increased risk of lung cancer. Also our results were in basic agreement with the results of Ergen et al. (2011) who found that PON1QQ genotype is a significant risk factor for osteosarcoma. However the results of Ferre et al. (2003) suggest that in addition to genetic factors other contributors such as nutrition and lifestyle do play an important role in determining PON1 enzyme activity. 
Nagwa S Ahmed et al

The conflicting results may be due to ethnic difference, sample size, and selection bias.

The present study demonstrated a significant alteration in the activity of PON1 in patient with CRC patients in relation to gene polymorphisms: the QQ genotype has lowest enzyme activity followed by, the QR genotype which has moderate activity, and the RR genotype has the highest enzyme activity. The Q192R polymorphism of the PON1 gene can also modify the affinities and catalytic activities of the enzyme PON1. The alloenzyme coded by $192 \mathrm{R}$ allele hydrolyzes different substrate faster than alloenzyme coded with PON1 192 Q alleles. However Q type isozyme allele is more efficient in protecting against low-density lipoprotein oxidation than the R-type (Aviram et al., 2000). As regards ARE, no significant change was observed among different PON1 Q192R genotypes. The causes are not known and must be investigated further.

As regards to PON1 L55M genotypes, our results indicated that the MM homozygous genotype has significant low enzymatic activity when compared to ML and LL genotypes, this result was in basic agreement with previous reports of Mackness et al. (1997). Nevin et al. (1996) reported that the PON1 genotype accounts for $76 \%$ of the variation in serum PON1 enzyme activity level. In addition, PON1 serum levels were modulated by disease state, dietary, lifestyle and environmental factors and therefore, may vary up to 13 -fold between individuals (Deakin and James, 2004; Draganov and La Du, 2004). L55 isoforms are more stable and resistant to proteolysis; this phenomenon partly explains their association with higher PON1 levels (Vecka et al., 2012). Moreover, human studies characterizing the PON1 polymorphisms have indicated the importance of estimating the PON1 status (i.e. genotype and phenotype taken together) rather than genotyping alone (Costa et al., 2003). The importance of PON1 as a predictive risk factor and its role in prognosis must be investigated. The limitation of present work is sample size and grouping of tumor pathology.

In conclusion, our results showed low PON1 and ARE enzyme activities in patients compared to control. Lower serum activity of PON1 returned to normal level after removal of the tumor. Also we showed that there is risk between PON1/55 and 192 and CRC. Moreover, we revealed that PON1 $192 \mathrm{R}$ has higher enzyme activity than PON192 Q. Similarly PON1 55M has less enzyme activity than PON1 $55 \mathrm{~L}$.

\section{References}

Aaltonen L, Johns L, Järvinen H, et al (2007). Explaining the familial colorectal cancer risk associated with mismatch repair (MMR)-deficient and MMR-stable tumors. Clin Cancer Res, 13, 356-61.

Adkins S, Gan KN, Mody M, La Du BN (1993). Molecular basis for the polymorphic forms of human serum paraoxonase/ arylesterase: glutamine or arginine at position 191, for the respective A or B allozymes. Am J Hum Genet, 52, 598-608.

Aiello M, Vella N, Cannavò C, et al (2011). Role of genetic polymorphisms and mutations in colorectal cancer therapy. Mol Med Rep, 4, 203-8.

Akkız H, Kuran s, Akgöllü e, et al (2013). Effect of PON1 gene polymorphisms in Turkish patients with hepatocellular carcinoma. Meta Gene, 1, 93-101.

Aksoy-Sagirli P, Cakmakoglu B, Isbir T, et al (2011): Paraoxonase-1 192/55 polymorphisms and the risk of lung cancer in a Turkish population. Anticancer Res, 31, 2225-30.

Alkhouri RH, Baker SS, Hashmi H, Liu W, Baker RD, Zhu L (2014): Paraoxonase gene expression in pediatric inflammatory bowel disease. Clin Cell Immunol, 5, 3 .

Antognelli C, Mearini L, Talesa VN, Giannantoni A, et al (2005). Association of CYP17, GSTP1, and PON1 polymorphisms with the risk of prostate cancer. Prostate, 63, 240-251

Arpaci A, 36355Görmüs U, 55Dalan B, 55Berkman S, 55Isbir $\mathrm{T}$ (2009): Investigation of PON1 192 and PON1 55 polym

Aviram M, Hardak E, Vaya J, et al (2000). Human serum paraoxonases (PON1) Q and R selectively decrease lipid peroxides in human coronary and carotid atherosclerotic lesions: PON1 esterase and peroxidase-like activities. Circulation, 101, 2510-7.

Balci H, Genc H, Papila C, et al (2012). Serum lipid hydroperoxide levels and paraoxonase activity in patients with lung, breast, and colorectal cancer. J Clin Lab Anal, 26, 155-60.

Bulbuller N, Eren E, Ellidag HY, et al (2013): Diagnostic value of thiol paraoxonase 1 , arylesterase and oxidative balance in colorectal cancer in human. Neoplasma, 60, 419-24.

Connolly JL, Schnitt SJ, Wang HH, Longtine JA, et al (2003). Principles of cancer pathology. in: Cancer Medicine (Kufe DW, Pollock RE and Weichselbaum RR, eds.). Hamilton-BC Decker, London, 487-502.

Costa LG, Cole TB, Furlong CE (2003). Polymorphisms of paraoxonase (PON1) and their significance in clinical toxicology of organophosphates. J Toxicol Clin Toxicol, 41, 37-45.

Davies HG, Richter RJ, Keifer M, Broomfield CA, Sowalla J, Furlong CE (1996). The effect of the human serum paraoxonase polymorphism is reversed with diazoxon, soman and sarin. Nat Genet, 14, 334-6.

Deakin SP, James RW (2004). Genetic and environmental factors modulating serum concentrations and activities of the antioxidant enzyme, paraoxonase-1. Clin Sci, 107, 435-47.

De Roos AJ, Gold LS, Wang S, et al (2006): Metabolic gene variants and risk of non-Hodgkin's lymphoma. Cancer Epidemiol Biomarkers Prev, 15, 1647-53.

Draganov DI, La Du BN (2004). Pharmacogenetics of paraoxonases: a brief review. Naunyn Schmiedebergs Arch Pharmacol, 369, 78.

Eckerson HW, Wyte CM, La Du BN (1983). The human serum paraoxonase/arylesterase polymorphism. Identification of phenotypes by their response to salts. Am J Hum Genet, 35, 214-27.

Ellidag HY, Eren EO, Neselioglu S, Yilmaz NJ (2014). Phenotype distribution of paraoxonase- 1 in patients with multiple myeloma, bladder, and colorectal cancer. Med Biochem, 33, 1-7.

Ergen A, Kilicoglu O, Ozger H, et al (2011). Paraoxonase 1 192 and 55 polymorphisms in osteosarcoma. Mol Biol Rep 38, 4181-4.

Ferré N, Camps J, Fernandez-Ballart J, et al (2003). Regulation of serum paraoxonase activity by genetic, nutritional and lifestyle factors in the general population. Clin Chem, 49, 1491-7.

Fossati P, Prencipe L (1982). Serum triglycerides determined colorimetrically with an enzyme that produces hydrogen peroxide. Clin Chem, 28, 2077-80.

Friedewald W, Levy R, Fedrickson D (1972): Estimation of the concentration of low-density lipoprotein cholesterol in plasma, without use of the preparative ultracentrifuge. Clin Chem, 18, 499-502. 
Gallicchio L, McSorley MA, Newschaffer CJ, et al (2007). Body mass, polymorphisms in obesity-related genes, and the risk of developing breast cancer among women with benign breast disease. Cancer Detect Prev, 31, 95-101.

Gold LS, De Roos AJ, Brown EE, et al (2009): Associations of common variants in genes involved in metabolism and response to exogenous chemicals with risk of multiple myeloma. Cancer Epidemiol, 33, 276-80.

Grove H (1979). Effect of reagent pH on determination of HDL cholesterol by precipitation with sodium phosphotungstatemagnesium. Clin Chem, 25, 560.

Hristozov D, Gadjeva V, Vlaykova T, Dimitrov G (2001). Evaluation of oxidative stress in patients with cancer. Arch Physiol Biochem.109 (4):331-6.

Hu Y, Wang JL, Tao HT, et al (2013). Expression and significance of TSGF, CEA and AFP in patients before and after radical surgery for colon cancer. Asian Pac J Cancer Prev, 14, 3877-80.

Jayakumari N, Thejaseebai G (2009). High prevalence of low serum paraoxonase- 1 in subjects with coronary artery disease. J Clin Biochem Nutr, 45, 278-84.

Kilic SS, Aydin S, Kilic N, et al (2005). Serum arylesterase and paraoxonase activity in patients with chronic hepatitis. World J Gastroenterol, 11, 7351-4.

Kumon Y, Suehiro T, Ikeda Y, Hashimoto K (2003). Human paraoxonase-1 gene expression by HepG2 cells is downregulated by interleukin- $1 \beta$ and tumor necrosis factor- $\alpha$, but is upregulated by interleukin-6. Life Sci, 73, 2807-15.

Lee CH, Lee KY, Choe KH, et al (2005). Effects of oxidative DNA damage induced by polycyclic aromatic hydrocarbons and genetic polymorphism of the paraoxonase-1 (PON1) gene on lung cancer. J Prev Med Pub Health, 38, 345-50.

Li HL, Liu DP, Liang CC (2003). Paraoxonase gene polymorphisms, oxidative stress, and diseases. J Mol Med, 81, 766-79.

Lichtenstein P, Holm NV, Verkasalo PK, et al (2000). Environmental and heritable factors in the causation of cancer-analyses of cohorts of twins from Sweden, Denmark, and Finland. N Engl J Med, 343, 78-85.

Lincz LF, Kerridge I, Scorgie FE, Bailey M, Enno A, Spencer A (2004): Xenobiotic gene polymorphisms and susceptibility to multiple myeloma. Haematologica, 89 (5): 628-629.

Loft S, Møller P, Cooke MS, Rozalski R, Olinski R (2008). Antioxidant vitamins and cancer risk: is oxidative damage to DNA a relevant biomarker? Eur J Nutr, 47 Suppl 2, 19-28.

Lurie G, Wilkens LR, Thompson PJ, et al (2008). Genetic polymorphisms in the paraoxonase 1 gene and risk of ovarian epithelial carcinoma. Cancer Epidemiol Biomarkers Prev, 17, 2070-7.

Mackness MI, Harty D, Bhatnagar D, et al (1991). Serum paraoxonase activity in familial hypercholesterolaemia and insulin-dependent diabetes mellitus. Atherosclerosis, 86, 193-9.

Mackness B, Mackness MI, Arrol S, Turkie W, Durrington PN (1997). Effect of the molecular polymorphisms of human paraoxonase (PON1) on the rate of hydrolysis of paraoxon. Br J Pharmacol, 122, 265-8.

Nevin DN, Zambon A, Furlong CE, et al (1996). Paraoxonase genotypes, lipoprotein lipase activity, and HDL. Arterioscler Thromb Vasc Biol, 16, 1243-9.

Oztürk O, Kağnici OF, Oztürk T, et al (2009). 192R allele of paraoxanase 1 (PON1) gene as a new marker for susceptibility to bladder cancer. Anticancer Res, 29, 4041-6.

Richmond W (1973). Enzymatic determination of cholesterol. Clin Chem, 19, 1350-6.

Stevens VL, Rodriguez C, Pavluck AL, Thun MJ, Calle EE
(2006). Association of polymorphisms in the paraoxonase 1 gene with breast cancer incidence in the CPS-II Nutrition Cohort. Cancer Epidemiol Biomarkers Prev, 15, 1226-8.

Unal E, Eris C, Kaya B, et al (2012). Paraoxonase and arylesterase activities, lipid profile, and oxidative damage in experimental ischemic colitis model. Gastroenterol Res Pract, 97, 950-6.

Van Der Logt EM, Janssen CH, Van Hooijdonk Z, et al (2005). No association between genetic polymorphisms in NAD $(\mathrm{P})$ H oxidase $\mathrm{p} 22$ phox and paraoxonase 1 and colorectal cancer risk. Anticancer Res, 25, 1465-70.

Vecka M, Jáchymová M, Vávrová L, et al (2012): Paraoxonase-1 (PON1) status in pancreatic cancer: relation to clinical parameters. Folia Biol, 58, 231-7.

Vermorken AJ, Zhu J, Andrès E (2014): Obesity and colorectal cancer risk: the role of oxidative stress. Gut, 63, 529-30. 